\title{
Growth and stem quality of hardwood trees planted 18-29 years ago on abandoned farmland following recommended silvicultural practices
}

\author{
by Alain Cogliastro ${ }^{1 * *}$ and Daniel Gagnon²
}

\begin{abstract}
The objective of this study is to provide an account of the growth results of valuable hardwood plantations several decades old which have received silvicultural treatments recommended for planting hardwoods on abandoned farmland. Diameter growth and stem quality of sugar maple (Acer saccharum Marsh.), black walnut (Juglans nigra L.), bur oak (Quercus macrocarpa Michx.) and red oak (Quercus rubra L.) are analysed. Data were from 15 plantations located in south-western Quebec. The mean annual diameter increments were highest for red oak $\left(0.83 \mathrm{~cm} \mathrm{yr}^{-1}\right)$ and black walnut $\left(0.75 \mathrm{~cm} \mathrm{yr}^{-1}\right)$, and lowest for bur oak $\left(0.55 \mathrm{~cm} \mathrm{yr}^{-1}\right)$ and sugar maple $\left(0.51 \mathrm{~cm} \mathrm{yr}^{-1}\right)$. These values are comparable to, or exceed, the best rates in the literature. A mean proportion of $78 \%$ to $95 \%$ of the first log without defects were produced, depending on the species. Tree mean densities (640 trees/ha) will allow a selection of better stems by thinning. Elite trees have diameters that are $17 \%$ to $23 \%$ above the average. These results lead us to believe in the potential for the production of quality hardwood timber in plantations in Québec.
\end{abstract}

Key words: open field plantation, log quality, soil preparation, herbicide application, pruning, thinning, southern Quebec

\section{RÉSUMÉ}

L'objectif de l'étude est de rendre compte de la croissance de plantations d'arbres feuillus, vieilles de quelques décennies, ayant reçu des traitements sylvicoles recommandés pour les terres agricoles abandonnées. La croissance en diamètre et la qualité des tiges d'érable à sucre (Acer saccharum Marsh.), de noyer noir (Juglans nigra L.), de chêne à gros fruits (Quercus macrocarpa Michx.) et de chêne rouge (Quercus rubra L.) sont analysées. Les données proviennent de quinze plantations localisées au sud-ouest du Québec. Les taux d'accroissement moyens en diamètre ont été les plus élevés pour les chênes rouges $\left(0,83 \mathrm{~cm} \mathrm{an}^{-1}\right)$ et les noyers noirs (moyenne $0,75 \mathrm{~cm} \mathrm{an}^{-1}$ ) et plus faibles pour les chênes à gros fruits $\left(0,55 \mathrm{~cm} \mathrm{an}^{-1}\right)$ et les érables à sucre $\left(0,51 \mathrm{~cm} \mathrm{an}^{-1}\right)$. Ces taux se comparent ou surpassent les meilleurs taux présentés dans la littérature. Une proportion moyenne de $78 \%$ à $95 \%$ de premières billes sans défauts a été produite. La densité moyenne (640 tiges/ha) permettrait une sélection des meilleures tiges. Le diamètre des arbres élites est de $17 \%$ à $23 \%$ supérieur à celui de tous les arbres. Ces résultats nous permettent de croire au potentiel de production de bois feuillus de qualité en plantation au Québec.

Mots clés: plantation en champ agricole abandonné, qualité des tiges, préparation des sols, application d'herbicide, taille de formation et d'élagage, éclaircie, Sud du Québec

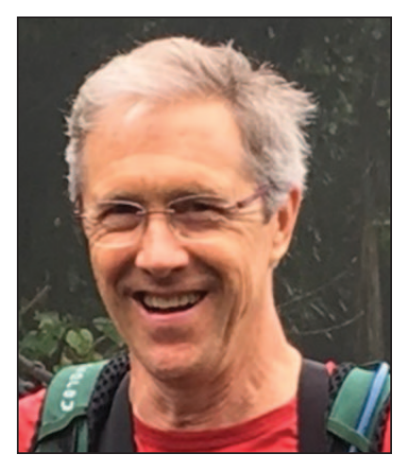

Alain Cogliastro

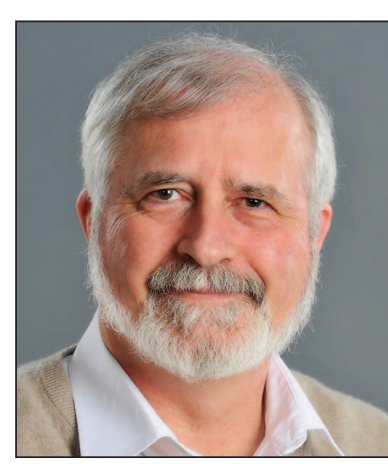

Daniel Gagnon

\begin{abstract}
Introduction
Hardwood planting on abandoned farmland (HPAF) in temperate regions has been the subject of several research investigations that have supported the development of silvicultural practices needed for successful tree survival and growth (Davies 1988; Cogliastro et al. 1990; West 2006). Plantation guides were developed based on these results (von Althen 1990; Allen et al. 2001; Farlee 2018). Jurisdictions, at various levels, agencies and private organisations, have sometimes developed programs for the promotion and financial support of hardwood plantations on abandoned farmland. However, many hardwood plantations were established without receiving all silvicultural treatments deemed essential to success, and the results obtained
\end{abstract}

\footnotetext{
${ }^{1}$ Jardin botanique de Montréal, Institut de recherche en biologie végétale, 4101 Sherbrooke Street East, Montréal, QC H1X 2B2 Canada ${ }^{*}$ Corresponding author

${ }^{2}$ Department of Biology, University of Regina, 3737 Wascana Parkway, Regina, SK, Canada, S4S 0A2
} 
varied highly and were often disappointing (Stanturf et al. 2001; Gardiner et al. 2002).

There are few studies that present growth and stem quality results of hardwoods planted two to three decades ago on different sites where basic silvicultural treatments were applied. Hardwood plantation studies more often discuss the effect of silvicultural treatments, often obtained at a single site. Also, hardwood plantation results are rarely about trees with sufficient size to allow evaluation of stem (log) quality. Knowing the likely potential growth range and the expected level of quality of the logs produced in hardwood plantations would be very useful for setting realistic objectives for the production of high value hardwood logs. Such results would also serve the needs of those planning plantations and who are motivated by environmental objectives, such as reducing the impact of intensive agriculture by agroforestry (Bergeron et al. 2011; Alam et al. 2014), creating forest corridors in highly deforested areas (Saura et al. 2017), and capturing $\mathrm{CO}_{2}$ emissions (Zhang et al. 2016). Results that can assist in estimating the growth of hardwood species in plantations on abandoned farmland, and where basic silvicultural treatments are applied, will be useful to such initiatives. The currently available references on hardwood growth generally originate from results obtained in forest environments (Lambert et al. 2005) and not from plantations.

The basic silvicultural treatments that are recognized as essential to success in HPAF include initial mechanical or chemical soil preparation, the selection of adapted species using good quality planting material, and planting according to a spacing adequate for the wide rooting system of the trees (von Althen 1990; Gardiner et al. 2002). Post-plantation treatments that are recognized as being the most important are the control of herbaceous plant competition by mechanical or chemical means, or by mulching (Cogliastro et al. 1990; Truax and Gagnon 1993), and protecting the planted trees from rodents (Ostfeld et al. 1997). Early formative pruning, as well as pruning to remove defects, should be applied at various frequencies (Hubert and Courraud 1998). Finally, thinning is also recommended for a constant and relatively rapid stem growth (Bohanek and Groninger 2003).

Diameter growth and the stem quality of sugar maple (Acer saccharum Marsh.), black walnut (Juglans nigra L.), bur oak (Quercus macrocarpa Michx.) and red oak (Quercus rubra L.) produced in plantations on abandoned farmland are analysed in this article. The data were obtained from 15 plantations located in south-western Quebec at the northern part of the distribution range of the species under study. However, the low elevation of the area (50 to $97 \mathrm{~m}$ a.s.l.) provides a warmer climate than what is found in much of the New England States, just south of the Canada/US border. The objective of this study is to give an account of the results of valuable hardwood plantations, several decades old, which have received the basic silvicultural treatments recommended for planting hardwoods on abandoned farmland. The ranges of growth rates and log quality have the potential to serve as references. We hope that these results encourage the establishment of programs that support investments in hardwood plantation silviculture in order that the majority of planted trees can produce the expected economic and environmental services.

\section{Methods}

\section{Study area description}

The hardwood plantations analysed are located in the Upper St. Lawrence region of south-western Québec. The plantations are distributed along a $60-\mathrm{km}$ east-west axis, (north to south maximum displacement from this axis is 20 $\mathrm{km}$ ), thus insuring relatively common climatic conditions. They are also distributed over the two major geological units of the region: dolomitic bedrock (Beekmantown group) in the western section and sandstone (Potsdam group) in the eastern section (Globensky 1987). These two geological units produce significantly different edaphic conditions (Bariteau 1988; Meilleur et al. 1994).

The region is characterized by an average frost-free period of 182 days (Huntingdon station, Lat. N: $45^{\circ} 4^{\prime} 50^{\prime \prime}$, Long. W: $\left.74^{\circ} 10^{\prime} 48^{\prime \prime}\right)$. Mean annual temperature is $7.0^{\circ} \mathrm{C}$ and monthly mean temperatures of July and January are $21.1^{\circ} \mathrm{C}$ and $-9.2^{\circ} \mathrm{C}$. Average annual precipitation in rain and snow are respectively $890 \mathrm{~mm}$ and $194 \mathrm{~mm}$ (MELCC 2010)

Of the 15 plantations analysed, five were established by a forestry consultant within the scope of forestry operations funded by a program to assist forest land owners. This fund was from the Quebec Ministry of Forests, Wildlife and Parks. The other 11 plantations were the initiative of the authors of this article to investigate the effects of various soil preparation treatments, competing vegetation control treatments, or differences in growth among different tree species. Only the trees that received the silvicultural treatments deemed essential are included in the analyses. The results from some of these plantations during their early years of growth have already been published (Cogliastro et al. 1997a, 1997b, 2003; Genet et al. 2013).

This study focuses on four hardwood species: sugar maple (Acer saccharum L.), black walnut (Jugans nigra L.), bur oak (Quercus macrocarpa Michx) and red oak (Quercus rubra L.). The trees range in age from 16 to 29 years of growth. Some plantations had white ash (Fraxinus americana L.) and red ash (F. pennsylvanica Marsh.), as well as butternut (Juglans cinerea L.), but these species were excluded from the study because of the insect (emerald ash borer) or disease (butternut canker) that affects them at a continental scale. A rapid survey of some these plantations in 2009 revealed an infection/death rate of over $75 \%$ of butternuts caused by the butternut canker (D. Gagnon, personal observation). The data for this article were collected from September to December 2016.

\section{Silvicultural treatments}

All plantation sites were abandoned from agriculture and were at the herbaceous old-field vegetation stage when they were converted to hardwood plantations. The bare root seedlings $(1+0$ or $2+0)$ used were produced by the provincial nursery of Quebec (Berthierville) which has excellent quality criteria. They were all planted manually during the spring (mostly in May). All seedlings received a plastic spiral protector, installed for five years minimum, to protect them from rodent damage.

Table 1 presents data on soil texture, tree species planted and the main silvicultural treatments at each plantation: soil preparation, weed control, deer browsing protection, pruning frequency. For Table 1 onwards, the name 
Table 1. Soil texture, hardwood species and silvicultural treatments applied at plantations

\begin{tabular}{|c|c|c|c|c|c|c|c|c|}
\hline Age-Site & te Latitude & Longitude & Soil texture & $\begin{array}{l}\text { Species } \\
\text { present }^{1}\end{array}$ & $\begin{array}{c}\text { Soil } \\
\text { preparation }^{2}\end{array}$ & $\begin{array}{l}\text { Post Planting } \\
\text { weed control }^{2}\end{array}$ & $\begin{array}{l}\text { Browsing } \\
\text { protection }^{3}\end{array}$ & $\begin{array}{c}\text { Number of } \\
\text { prunings }\end{array}$ \\
\hline 16-La 4 & $45^{\circ} 3^{\prime} 51.00^{\prime \prime} \mathrm{N}$ & $74^{\circ} 16^{\prime} 34.78^{\prime \prime} \mathrm{O}$ & stony loam & JUN & $(\mathrm{S}) \mathrm{P}+\mathrm{D}$ & (S)PM & Years $1,2,3$ & 3 \\
\hline $17-\mathrm{V} \quad 4$ & $45^{\circ} 13^{\prime} 52.99^{\prime \prime} \mathrm{N}$ & $73^{\circ} 40^{\prime} 20.99^{\prime \prime} \mathrm{O}$ & stony loam & JUN & $(\mathrm{S}) \mathrm{P}+\mathrm{D}$ & (S)PM & Year 3 & 4 \\
\hline $18-\mathrm{P}$ & $45^{\circ} 4^{\prime} 36.77^{\prime \prime} \mathrm{N}$ & $74^{\circ} 13^{\prime} 51.97^{\prime \prime} \mathrm{O}$ & stony loam & QUR-JUN & $(\mathrm{S}) \mathrm{P}+\mathrm{D}$ & (S)PM & nil & 4 \\
\hline 19-D & $45^{\circ} 3^{\prime} 2.51^{\prime \prime} \mathrm{N}$ & $74^{\circ} 5^{\prime} 37.60^{\prime \prime} \mathrm{O}$ & sandy loam & JUN & $\mathrm{P}+\mathrm{D}$ & PM & nil & 5 \\
\hline $21-\mathrm{D}$ & $45^{\circ} 3^{\prime} 0.98^{\prime \prime} \mathrm{N}$ & $74^{\circ} 5^{\prime} 38.66^{\prime \prime} \mathrm{O}$ & sandy loam & ACS & $\mathrm{H}+\mathrm{P}+\mathrm{D}$ & $\mathrm{PM}$ & nil & 5 \\
\hline 26-I & $45^{\circ} 1^{\prime} 36^{\prime \prime} \mathrm{N}$ & $73^{\circ} 58^{\prime} 40^{\prime \prime} \mathrm{O}$ & sandy loam & QUM-QUR-ACS-JUN & $\mathrm{NP}$ & $\mathrm{H}$ years 1 to $4+\mathrm{CM}$ & nil & 2 \\
\hline $26-\mathrm{M}$ & $45^{\circ} 2^{\prime} 38^{\prime \prime} \mathrm{N}$ & $74^{\circ} 22^{\prime} 15^{\prime \prime} \mathrm{O}$ & sand & QUM-QUR-ACS-JUN & NP & $\mathrm{H}$ years 1 to $4+\mathrm{CM}$ & nil & 3 \\
\hline $27-\mathrm{Lb}$ & $45^{\circ} 4^{\prime} 34^{\prime \prime} \mathrm{N}$ & $74^{\circ} 17^{\prime} 10^{\prime \prime} \mathrm{O}$ & stony loam & QUM & $\begin{array}{c}\mathrm{NP} / \mathrm{P}+ \\
\mathrm{D} / \mathrm{P}+\mathrm{D}+\mathrm{Hs}\end{array}$ & $\begin{array}{c}(\mathrm{S}) \mathrm{PM} /(\mathrm{S}) \\
\text { H years } 1 \text { to } 5\end{array}$ & nil & 4 \\
\hline 27-Lt & $45^{\circ} 2^{\prime} 18^{\prime \prime} \mathrm{N}$ & $74^{\circ} 23^{\prime} 39^{\prime \prime} \mathrm{O}$ & sand & QUR & $\mathrm{P}+\mathrm{D}$ & $\mathrm{PM}$ & nil & 2 \\
\hline $27-\mathrm{R}$ & $45^{\circ} 4^{\prime} 4^{\prime \prime} \mathrm{N}$ & $74^{\circ} 19^{\prime} 22^{\prime \prime} \mathrm{O}$ & clay loam & ACS-QUR & $\mathrm{P}+\mathrm{D}$ & $\mathrm{H}$ year 3 & nil & 2 \\
\hline $28-\mathrm{M}$ & $45^{\circ} 2^{\prime} 38^{\prime \prime} \mathrm{N}$ & $74^{\circ} 22^{\prime} 16^{\prime \prime} \mathrm{O}$ & sand & QUR & $\mathrm{P}+\mathrm{D}$ & $\mathrm{PM} / \mathrm{H}$ years $1,2,3,5$ & nil & 6 \\
\hline 29-C & $45^{\circ} 6^{\prime} 43^{\prime \prime} \mathrm{N}$ & $74^{\circ} 17^{\prime} 44^{\prime \prime} \mathrm{O}$ & stony loam & QUM-QUR & $\mathrm{P}+\mathrm{D}$ & WM/H years $1,2,3,5$ & nil & 5 \\
\hline 29-H & $45^{\circ} 5^{\prime} 40^{\prime \prime} \mathrm{N}$ & $74^{\circ} 16^{\prime} 46^{\prime \prime} \mathrm{O}$ & stony loam & QUM-QUR & $\mathrm{P}+\mathrm{D}$ & WM/H years $1,2,3,5$ & nil & 5 \\
\hline 29-M & $45^{\circ} 2^{\prime} 39^{\prime \prime} \mathrm{N}$ & $74^{\circ} 22^{\prime} 19^{\prime \prime} \mathrm{O}$ & sand & QUM-QUR & $\mathrm{P}+\mathrm{D}$ & $\mathrm{WM} / \mathrm{H}$ years $1,2,3,5$ & nil & 5 \\
\hline $29-S$ & $45^{\circ} 7^{\prime} 4^{\prime \prime} \mathrm{N}$ & $74^{\circ} 22^{\prime} 18^{\prime \prime} \mathrm{O}$ & clay & QUM-QUR & $\mathrm{P}+\mathrm{D}$ & WM/H years $1,2,3,5$ & nil & 5 \\
\hline
\end{tabular}

${ }^{1} \mathrm{ACS}=$ Acer saccharum, JUN=Juglans nigra, QUM= Quercus macrocarpa, QUR= Quercus rubra

${ }^{2} \mathrm{CM}=$ cardboard mulch; $\mathrm{D}=$ disking; $\mathrm{H}=$ herbicide glyphosate; $\mathrm{Hs}=$ herbicide simazine; $\mathrm{NP}=$ no soil preparation; $\mathrm{P}=$ plowing; $\mathrm{PM}=$ plastic mulch; $\mathrm{S}=$ strip; $\mathrm{WM}=$ wood mulch;

${ }^{3}$ Deer away ${ }^{\mathrm{TM}}$ application

for each plantation combines plantation age and the first letter of the name of the landowner (e.g., plantation 29-C, 29 years of growth on the property of Mr. Caza).

Soil texture varies from sandy to clay, with many loams that are sometimes stony (Table 1). Mechanical soil preparation by plowing and disking was done at 12 sites. This soil preparation was done either on the entire plot or in strips 1.5 to $1.8 \mathrm{~m}$ in width (Table 1). At these plantations, postplanting weed control treatments were done using glyphosate herbicide (Roundup ${ }^{\mathrm{TM}}$, Monsanto Technology LLC, St. Louis, MO, USA), or black plastic mulch in strips $120-\mathrm{cm}$ wide or with wood chip mulch over a $1 \mathrm{~m}^{2}$ area and $5 \mathrm{~cm}$ in thickness (Table 1).

Two plantations (26-M, 26-I) did not receive mechanical soil preparation but only post-planting weed control treatment with glyphosate (Table 1). The herbicide treatment in this case was applied over the entire plot in the first year, and in a radius of $60 \mathrm{~cm}$ around the seedlings in the second year. For these two plantations, a $0.81 \mathrm{~m}^{2}(0.9 \mathrm{~m} \mathrm{X}$ $0.9 \mathrm{~m}$ ) cardboard-type mulch (Cellufib", Cascades Etcan Inc., Cabano, PQ, Canada) was installed in the third year at the base of each seedling and glyphosate was applied at the margins with a wick applicator (Table 1). The wick application was repeated in the fourth year. One other plantation had a third of its plots that did not receive soil mechanical preparation (27-Lb), but where a post-planting weed control treatment with glyphosate or a black plastic mulch was applied in strips $120-\mathrm{cm}$ width (Table 1 ). In this case, two herbicide applications were made in the first year and one per year during the following four years.

Deer density having gradually increased in the region, the more recent plantations $(16-\mathrm{La}, 17-\mathrm{V})$ received deer browsing protection treatments using a deer repellent (Deer Away ${ }^{\mathrm{R}}$ Miller Chemical and Fertilizer, Hanover, PA, USA) (Table 1). Shaping and pruning procedures were done twice at three plantations, three times at two planta- tions, four times at two plantations, five times at six plantations, and six times at one plantation (Table 1).

\section{Density and thinning}

For each species, the area occupied, initial and residual densities, and number of sampled trees in each plantation are presented in Table 2. Several plantations occupy a relatively small area because they were originally planned for research objectives for which it was preferable to have more sites in order to increase edaphic variation. This is the case for 26-M and 26-I, as well as for 29-C, 29-H, 29-M and 29-S (Table 2). The plantations were generally planted at 2000 to $2500 \mathrm{stems} / \mathrm{ha}$, according to the guidelines for the region at that time (Table 2). However, some experimental plantations were planted at a lower density. This is the case for plantations containing black walnut (16-La, $17-\mathrm{V}$ and 18-P). For this species, European publications suggested wider spacing (Becquey 1997; Balleux and van Lerberghe 2001). A thinning cut was done in nine plantations (between 18 to 22 years old), and one plantation had two thinning cuts (28-M) (at 12 years and at 21 years) (Table 2). The stems cut in the thinning operations were left on site or used as firewood. The residual density at the time the data were collected (2016), a result of both mortality and thinning, was on average $25 \%$ of the initial density, with a minimum of $14 \%$ and a maximum of $58 \%$ (Table 2). The residual trees had a mean density of 642 stems per hectare, ranging from 350 to 1480 stems/ha (Table 2).

\section{Tree sampling and measurement}

The number of trees measured per species at each plantation is shown in Table 2. Depending on the size of the plantations, from $10 \%$ to $100 \%$ of the trees were selected to be measured. In the case of plantations with large areas of a single species, 15 consecutive trees were measured in sections of three different rows. The rows chosen for sam- 
Table 2. Area occupied, initial and residual densities, thinning frequency and number of sampled trees for each species at each plantation

\begin{tabular}{|c|c|c|c|c|c|c|}
\hline Species & $\begin{array}{l}\text { Age- } \\
\text { Site }\end{array}$ & $\begin{array}{l}\text { Area / } \\
\mathrm{sp}\left(\mathrm{m}^{2}\right)\end{array}$ & $\begin{array}{c}\text { Initial } \\
\text { Tree/ha }\end{array}$ & $\begin{array}{l}\text { Thinning } \\
\text { frequency }\end{array}$ & $\begin{array}{l}\text { Residual } \\
\text { Tree/ha }\end{array}$ & $\begin{array}{c}\text { Sam- } \\
\text { pling } \\
\text { (n) }\end{array}$ \\
\hline ACS & $21-\mathrm{D}$ & 3510 & 2500 & 1 & 1450 & 30 \\
\hline ACS & 26-I & 300 & 2500 & 1 & 668 & 15 \\
\hline ACS & 26-M & 300 & 2500 & 1 & 475 & 11 \\
\hline ACS & $27-\mathrm{R}$ & 2500 & 2000 & 0 & 1480 & 45 \\
\hline JUN & $16-\mathrm{La}$ & 1855 & 555 & 0 & 455 & 42 \\
\hline JUN & $17-\mathrm{V}^{*}$ & 3220 & 410 & 0 & 377 & 53 \\
\hline JUN & $18-\mathrm{P}$ & 3240 & 833 & 0 & 708 & 92 \\
\hline JUN & $19-\mathrm{D}$ & 1000 & 2500 & 1 & 1071 & 30 \\
\hline JUN & 26-I & 300 & 2500 & 1 & 468 & 14 \\
\hline JUN & $26-\mathrm{M}$ & 300 & 2500 & 1 & 400 & 9 \\
\hline QUM & 26-I & 300 & 2500 & 1 & 668 & 14 \\
\hline QUM & $26-\mathrm{M}$ & 300 & 2500 & 1 & 425 & 7 \\
\hline QUM & $27-\mathrm{Lb}$ & 6480 & 2222 & 1 & 706 & 60 \\
\hline QUM & $29-\mathrm{C}$ & 480 & 2500 & 1 & 480 & 18 \\
\hline QUM & $29-\mathrm{H}$ & 480 & 2500 & 1 & 812 & 26 \\
\hline QUM & $29-\mathrm{M}$ & 480 & 2500 & 1 & 350 & 13 \\
\hline QUM & $29-S$ & 480 & 2500 & 1 & 550 & 19 \\
\hline QUR & $18-\mathrm{P}$ & 3240 & 833 & 0 & 733 & 95 \\
\hline QUR & 26-I & 300 & 2500 & 1 & 700 & 15 \\
\hline QUR & 26-M & 300 & 2500 & 1 & 500 & 15 \\
\hline QUR & $27-\mathrm{Lt}$ & 6000 & 2000 & 1 & 756 & 45 \\
\hline QUR & $27-\mathrm{R}$ & 5000 & 2000 & 0 & 860 & 44 \\
\hline QUR & $28-\mathrm{M}$ & 1765 & 2500 & 2 & 425 & 49 \\
\hline QUR & $29-\mathrm{C}$ & 480 & 2500 & 1 & 416 & 17 \\
\hline QUR & $29-\mathrm{H}$ & 480 & 2500 & 1 & 500 & 19 \\
\hline QUR & $29-\mathrm{M}$ & 480 & 2500 & 1 & 458 & 14 \\
\hline QUR & $29-S$ & 480 & 2500 & 1 & 450 & 18 \\
\hline
\end{tabular}

* Walnut rows intercropped with poplar rows $(6 \mathrm{~m} \times 3 \mathrm{~m})$

Table 3. Defects recorded on each of the four faces of a log

\begin{tabular}{|c|c|}
\hline Default & Description \\
\hline Lower bole injury & Injury on the but log \\
\hline Bump & Protuberance on the bole \\
\hline Large branch & Branches $>5 \mathrm{~cm}$ diameter \\
\hline Epicormic branch & $\begin{array}{c}\text { Twigs }>1 \mathrm{~cm} \text { diameter or two and } \\
\text { more twigs in a radius of } 15 \mathrm{~cm}\end{array}$ \\
\hline Canker & $\begin{array}{l}\text { Lesion on the bole of a tree caused by } \\
\text { a fungus growth }\end{array}$ \\
\hline Check & Sudden axis deviation \\
\hline Sweep & Gradual axis deviation \\
\hline Frost crack & Spiralized, deep or superficial cracks \\
\hline Fork & Main stem division \\
\hline Knots & Trace left by an old branch \\
\hline Sapsucker peck & $\begin{array}{l}\text { Small holes made by the yellow-bellied } \\
\text { sapsucker }\end{array}$ \\
\hline Conks & Fungal presence \\
\hline
\end{tabular}

pling were located in different areas of the plantation and excluded trees on plantation edges. No sampled trees were selected based on apparent tree quality. The initial and current densities of the trees were determined by measuring available data, confirmed by measuring the space between planting rows and the spacing on the rows. A total of 829 trees were measured, including 331 red oaks in
Table 4. Diameter at breast height (DBH; $\mathrm{cm})$, height $(\mathrm{m})$ and height/DBH ratio (and standard deviation SD) for each species at each age-site

\begin{tabular}{|c|c|c|c|c|c|c|c|}
\hline Species & Age-Site & $\mathrm{DBH}$ & SD & Height & SD & H/D & SD \\
\hline ACS & $21-\mathrm{D}$ & 11.2 & 3.7 & 10.3 & 2.8 & 0.95 & 0.20 \\
\hline ACS & $26-\mathrm{I}$ & 14.5 & 2.8 & 12.5 & 2.0 & 0.87 & 0.14 \\
\hline ACS & $26-\mathrm{M}$ & 16.1 & 5.5 & 12.0 & 3.3 & 0.77 & 0.11 \\
\hline ACS & $27-\mathrm{R}$ & 8.6 & 3.1 & 8.2 & 2.5 & 0.98 & 0.15 \\
\hline JUN & $16-\mathrm{L}$ & 14.9 & 3.7 & 9.2 & 2.1 & 0.62 & 0.06 \\
\hline JUN & $17-\mathrm{V}^{\star}$ & 11.6 & 3.4 & 7.9 & 2.0 & 0.70 & 0.09 \\
\hline JUN & $18-\mathrm{P}$ & 16.1 & 4.5 & 10.5 & 2.3 & 0.67 & 0.09 \\
\hline JUN & $19-\mathrm{D}$ & 13.6 & 4.3 & 9.4 & 2.4 & 0.71 & 0.12 \\
\hline JUN & $26-\mathrm{I}$ & 18.5 & 3.3 & 11.2 & 1.2 & 0.61 & 0.07 \\
\hline JUN & $26-\mathrm{M}$ & 15.2 & 5.4 & 11.8 & 3.9 & 0.79 & 0.11 \\
\hline QUM & $26-I$ & 14.0 & 2.2 & 9.0 & 1.4 & 0.65 & 0.08 \\
\hline QUM & 26-M & 17.8 & 3.4 & 10.6 & 1.1 & 0.60 & 0.07 \\
\hline QUM & 27-Lb & 9.9 & 2.4 & 6.8 & 1.3 & 0.69 & 0.05 \\
\hline QUM & $29-C$ & 18.4 & 4.4 & 11.2 & 2.2 & 0.62 & 0.06 \\
\hline QUM & $29-\mathrm{H}$ & 14.9 & 4.4 & 9.8 & 2.4 & 0.67 & 0.09 \\
\hline QUM & 29-M & 15.1 & 2.9 & 10.7 & 1.9 & 0.71 & 0.09 \\
\hline QUM & $29-S$ & 17.8 & 5.0 & 11.1 & 2.1 & 0.64 & 0.10 \\
\hline QUR & $18-\mathrm{P}$ & 14.1 & 3.8 & 10.2 & 2.2 & 0.74 & 0.09 \\
\hline QUR & $26-\mathrm{I}$ & 23.3 & 4.0 & 14.9 & 1.6 & 0.66 & 0.11 \\
\hline QUR & 26-M & 22.0 & 5.2 & 14.8 & 3.3 & 0.68 & 0.06 \\
\hline QUR & $27-\mathrm{Lt}$ & 15.1 & 5.2 & 11.8 & 3.7 & 0.80 & 0.17 \\
\hline QUR & 27-R & 18.8 & 4.8 & 14.3 & 2.9 & 0.79 & 0.18 \\
\hline QUR & $28-\mathrm{M}$ & 25.9 & 4.9 & 18.2 & 3.3 & 0.71 & 0.07 \\
\hline QUR & $29-\mathrm{C}$ & 24.8 & 8.0 & 15.3 & 3.1 & 0.66 & 0.17 \\
\hline QUR & $29-\mathrm{H}$ & 26.6 & 6.1 & 17.4 & 3.7 & 0.67 & 0.10 \\
\hline QUR & 29-M & 27.8 & 5.9 & 18.7 & 3.1 & 0.68 & 0.07 \\
\hline QUR & $29-S$ & 25.9 & 5.2 & 16.4 & 2.2 & 0.66 & 0.18 \\
\hline
\end{tabular}

* Walnut rows intercropped with poplar rows $(6 \mathrm{~m} \times 3 \mathrm{~m})$

10 plantations, 240 black walnuts in six plantations, 157 bur oaks in seven plantations, and 101 sugar maples in four plantations (Table 2).

Diameter at breast height (DBH; $1.3 \mathrm{~m}$ above ground) outside the bark was measured and the mean DBH per species per plantation is presented (Table 4). Stem quality evolution is positively related to diameter growth (Power and Havreljuk 2016). The mean diameter of trees with a DBH above the median (50\%) was also calculated and termed « $\mathrm{DBH}(+50 \%)$ ». These larger trees would be part of the trees retained at the next thinning. The mean annual diameter increment (ADI) and the mean ADI (+50\%) were also calculated. The height of trees was measured for a subsample of trees selected to cover the range of diameters of each species in each plantation. Thus, depending on the species, $38 \%$ to $62 \%$ of trees were measured for height. Height measurements were made with a hypsometer (Vertex III, Haglöf Sweden AB, Längsele, Sweden). Regressions for height based on $\mathrm{DBH}$ for each species were used to determine a height value for the trees that were measured only for DBH (Jump statistical software, JMP v10.0.0; SAS Institute, Cary, NC, USA).

The defects of the four faces of each stem were determined using the document produced by the Quebec Min- 
istry of Forests, Wildlife and Parks (MFFP 2014) (Table 3). Two stem quality evaluators were trained for two days by two specialists to insure that the stem quality evaluation method was well understood and accurately applied. Stems were evaluated for their potential to provide two log sections of $2.6 \mathrm{~m}$ (8'6") with a maximum of faces without defects. In cases where obtaining only a single log section was possible, we determined the length of the first log that would maximize the number of faces clear of defects.

All defects were evaluated and the most important defect was recorded for each log. The presence of branches of $5-\mathrm{cm}$ diameter or less on stems with diameters smaller than $12-\mathrm{cm}$ was not considered a defect because the next pruning could ensure that quality is maintained. These branches were rarely present on the first log because pruning had been previously done in all plantations.

\section{Results and discussion}

Soil preparation and post-planting weed control treatments have resulted in a generally high survival rate, and plantations with the highest initial densities (> $2000 \mathrm{t} / \mathrm{ha}$ ) have received a thinning treatment (Table 2). One of these plantations received only one post-planting herbicide treatment in the third year (plantation 27-R, Table 1) and the survival of red oak was the lowest at $43 \%$ (residual tree $\mathrm{ha}^{-1} /$ initial tree $\mathrm{ha}^{-1}$, Table 2 ), reducing the need for the first thinning in this plantation (Tables 1 and 2). In this same plantation, sugar maple and red oak $\mathrm{DBH}$ and height values were among the lowest compared to other plantations of similar age (26-29 years old) (Table 4).

The mean variability in diameter values for each species at each plantation varied from $22 \%$ to $30 \%$. A significant number of trees with larger diameters is therefore present. Variability is less for height (18\% to $25 \%)$, and even more so for the H/D ratio ( $11 \%$ to $17 \%$ ) (Table 4$)$.

\section{Growth results}

\section{Sugar maple}

Mean annual diameter increment (ADI) for sugar maple varies from 0.53 to $0.62 \mathrm{~cm} \mathrm{yr}^{-1}$ in three of four study plantations (Fig. 1). The lowest ADI values were obtained in plantation $27-\mathrm{R}\left(0.32 \mathrm{~cm} \mathrm{yr}^{-1}\right)$, for which we have already mentioned a minimum herbaceous vegetation control effort (Fig. 1; Table 4). Growth data from nine experimental plantations (19 to 31 years old) reported by McKenney et al. (2008) showed an average ADI rate of $0.35 \mathrm{~cm} \mathrm{yr}^{-1}$, with a maximum value of $0.49 \mathrm{~cm} \mathrm{yr}^{-1}$. Lamson and Smith (1978) measured a mean ADI of $0.47 \mathrm{~cm} \mathrm{yr}^{-1}$ for 14 -yearold sugar maples originating from natural seedlings thinned at nine years. The elite sugar maple trees of our study have an ADI $+50 \%$ ranging from 0.64 to $0.76 \mathrm{~cm} \mathrm{yr}^{-}$ 1 in three of our four plantations, and of $0.41 \mathrm{~cm} \mathrm{yr}^{-1}$ in plantation 27-R. With more than 475 trees ha-1 (Table 2), the selection of superior trees can be considered in all our

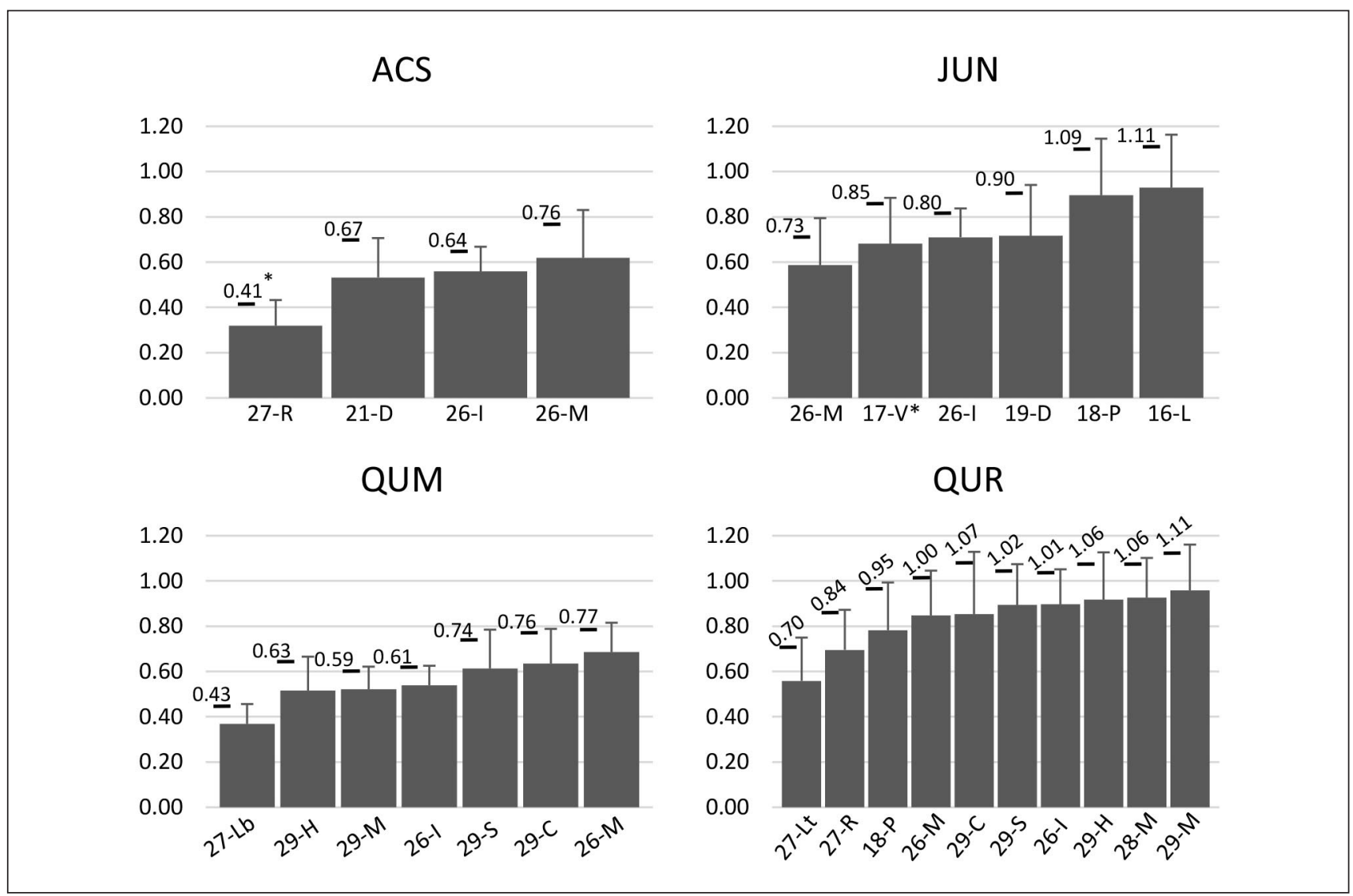

Fig. 1. Bar graphs of annual diameter increment $(A D I, c m)$ and standard deviation for each species at each plantation (age-site). ${ }^{*} T h e$ underlined values above the bar graphs are the mean value of the ADI (cm) of the $50 \%$ of trees that have the largest diameter in each plantation. 
plantations, which could lead to a $23 \%$ mean improvement of the ADI (Table 4).

\section{Black walnut}

The average ADI from black walnut ranged between 0.59 to $0.93 \mathrm{~cm} \mathrm{yr}^{-1}$ (Fig. 1), depending on the plantation. The diameter values obtained for black walnut (Table 4, Fig. 1) are comparable to the best results for the species among those obtained in Canadian hardwood plantations in studies by Pedlar et al. (2006) (26 years, $16.4 \mathrm{~cm} \mathrm{DBH,}$ $\left.0.62 \mathrm{~cm} \mathrm{yr}^{-1} \mathrm{ADI}\right)$ and by Pedlar et al. (2007) (20 \& 30 years, $13.6 \mathrm{~cm} \& 20.2 \mathrm{~cm} \mathrm{DBH}, 0.68 \mathrm{~cm} \& 0.67 \mathrm{~cm} \mathrm{ADI)}$. The superior results of these studies were obtained in mixed plantations, on well-drained loamy or sandy loam soils considered optimal in Ontario (Canada). Our results in Québec were obtained on well-drained stony loam or sandy loam soils (Table 1). Our ADI values are, in general, higher than the ADI of $0.60 \mathrm{~cm} \mathrm{yr}^{-1}$ considered "typical" in Indiana (Woeste 2002). Bohanek and Groninger (2003) obtained a mean ADI rate of $0.80 \mathrm{~cm} \mathrm{yr}^{-1}(\mathrm{DBH}=28.2 \mathrm{~cm}$ after 35 years) for black walnut in Illinois in an intensive silvicultural trial with a density of 158 trees $\mathrm{ha}^{-1}$. The black walnut plantations in our study have current densities ranging from 377 to 1071 trees $^{-1} \mathrm{a}^{-1}$, making future thinning possible (Table 2). Our elite black walnuts, (ADI + $50 \%)$, have ADI rates ranging from 0.73 to $1.11 \mathrm{~cm} \mathrm{yr}^{-1}$, with five of our six plantations yielding ADI rates above $0.80 \mathrm{~cm} \mathrm{yr}^{-1}$ (Fig. 1). These values correspond to an increase of $21 \%$ in mean ADI.

\section{Bur oak}

Three plantations have the highest ADI values for bur oak, ranging from 0.61 to $0.69 \mathrm{~cm} \mathrm{yr}^{-1}$ (Fig. 1). A second group of three plantations produced intermediate ADI values (0.52 to $0.54 \mathrm{~cm} \mathrm{yr}^{-1}$ ) (Fig. 1). The ADI and tree diameter were the lowest in plantation 27-Lb, with an ADI of $0.43 \mathrm{~cm} \mathrm{yr}^{-1}$ (Fig. 1, Table 4). The soil in plantation 27-Lb is relatively thin with bedrock at $80 \mathrm{~cm}$ depth, and with a soil rockiness of 30-40\% (Cogliastro et al. 2003). These characteristics limit the soil volume that can be prospected by roots. The plantation also drains and dries up more rapidly than others because of its higher topographic position.

ADI results of $0.30 \mathrm{~cm} \mathrm{yr}^{-1}$ and $0.39 \mathrm{~cm} \mathrm{yr}^{-1}$ were produced by 25-year-old trees on two plots of the same Ontario plantation site (McKenney et al. 2008). The initial densities of these two plots were high, with respectively 3630 and 2238 trees/ha. Johnson (1990) reported a bur oak ADI ranging from 0.25 to $0.64 \mathrm{~cm} \mathrm{yr}^{-1}$ in Iowa and a mean ADI of $0.65 \mathrm{~cm} \mathrm{yr}^{-1}$ in Kansas. The most productive bur oaks of our study (ADI $+50 \%)$ attain or surpass these higher values ( 0.59 to $0.77 \mathrm{~cm} \mathrm{yr}^{-1}$; Fig. 1$)$, with the exception of bur oaks in plantation 27-Lb (Fig. 1). Our bur oak $\mathrm{ADI}+50 \%$ values are on average $17 \%$ higher than the mean ADI. Tree densities in our plantations will allow a selection of better stems by thinning. Bur oak growth is about half as rapid as that of red oak (Johnson et al. 2009; Truax et al. 2015).

\section{Red oak}

The mean ADI of red oak was higher than $0.80 \mathrm{~cm} \mathrm{yr}^{-1}$ in seven of the 10 plantations studied (Fig. 1). The lower ADI values in the remaining three plantations (27-Lt; 27-R; 18-P) ranged from 0.56 to $0.78 \mathrm{~cm} \mathrm{yr}^{-1}$. The red oak of plantation 18 -P were planted at a spacing of $2 \mathrm{~m} \mathrm{x} 6 \mathrm{~m}$. The $2 \mathrm{~m} \mathrm{spac}-$ ing on the row and the absence of a thinning treatment (Table 2) were probably growth limiting. We have already mentioned that the single herbicide application in plantation 27-R could explain the slower growth of sugar maple. This would seem to be the case as well for red oak. Plantation 27-Lt could have some of the lowest growth results because the thinning operation occurred late. The three plantations, 27-Lt, 27-R and 18-P, are also those that have the highest H/D ratios for red oak, which likely reflects the effect of a high planting density (Bartoli and Golf 1994).

From the analysis of four experimental plantations of 35 and 36 years of age, McKenney et al. (2008) obtained a mean ADI of $0.47 \mathrm{~cm} \mathrm{yr}^{-1}$, producing red oak with a mean DBH of $16 \mathrm{~cm}$. In red oak plantations of south western France, mean ADI values of $0.9 \mathrm{~cm} \mathrm{yr}^{-1}( \pm 0.16)$ were measured at 20-30 years of growth (Timbal et al. 1994). Ward (2002) measured ADI from 0.50 to $0.65 \mathrm{~cm} \mathrm{yr}^{-1}$ for forest grown red oak ranging from 74 to 94 years that had received a crown release of $50 \%$ or higher. Johnson (2009) reported ADI values from 0.72 to $1.02 \mathrm{~cm} \mathrm{yr}^{-1}$ in red oak following thinning operations at several average natural sites. The elite red oak of our study have, on average, an $\mathrm{ADI}+50 \%$ that is $19 \%$ higher than the mean ADI, with values ranging between 1.0 and $1.11 \mathrm{~cm} \mathrm{yr}^{-1}$ at seven of 11 plantations (Fig. 1).

\section{Stem quality}

Sugar maple with a first log without defects occur in the four plantations that were planted for over $84 \%$ of trees, with two plantations that have $100 \%$ of trees with a first log without defects (Fig. 2A). At three of these plantations, a second $\log$ without defects is present for $27 \%, 29 \%$ and $37 \%$ of the trees (Fig. 2B).

Four plantations with black walnut had more than $74 \%$ of the trees with a first log without defects, with two plantations with $93 \%$ and one plantation with $85 \%$ (Fig. 2C). The other two plantations had $56 \%$ and $67 \%$ of black walnut with a first $\log$ without defects (Fig. 2C). Five plantations had from $10 \%$ to $21 \%$ of black walnut that have a second $\log$ without defects on four faces, and the last plantation (16-La) had no second log of interest (Fig. 2D).

First logs for bur oak were $100 \%$ without defects at five of our seven plantations (Fig. 2E). The two other plantations had $77 \%$ and $86 \%$ of trees with perfect first logs (Fig. 2E). Two plantations had $44 \%$ and $58 \%$ of their second logs without defects, two other plantations had $29 \%$ and $19 \%$ perfect second logs, one plantation had only $7 \%$, and two plantations had no perfect second log (Fig. 2F). The addition of bur oak second logs with three perfect faces provides a significant increase in bur oak value in these plantations (Fig. 2F). 

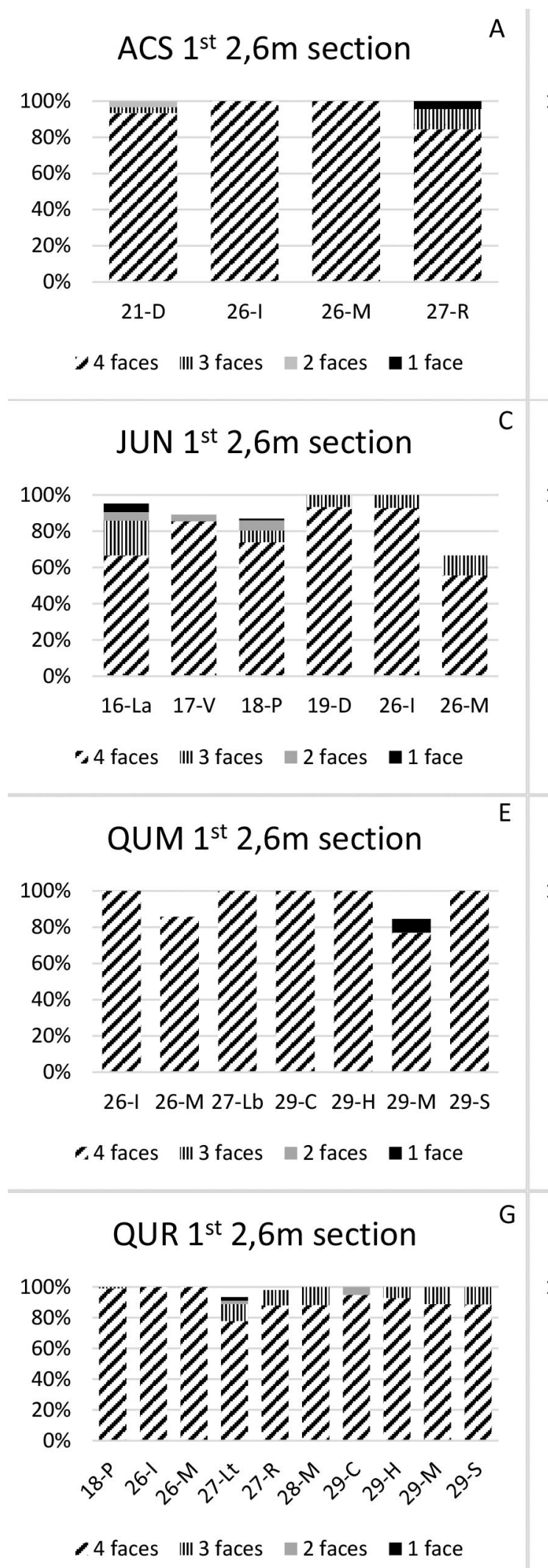

ACS $2^{\text {nd }} 2,6 m$ section

B

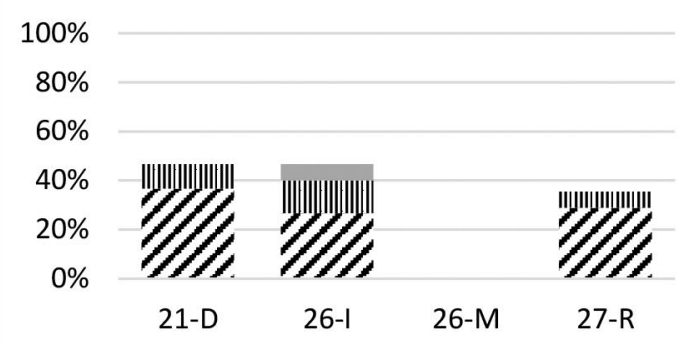

C. 4 faces III 3 faces $\quad 2$ faces 1 face

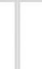

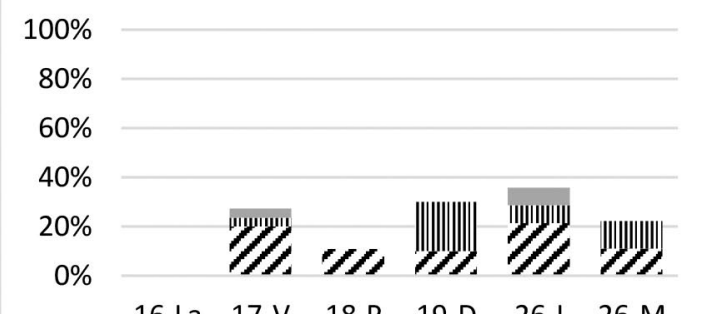

16-La $\quad 17-\mathrm{V} \quad 18-\mathrm{P} \quad 19-\mathrm{D} \quad 26-\mathrm{I} \quad 26-\mathrm{M}$

$>4$ faces III 3 faces $\quad 2$ faces $\square 1$ face

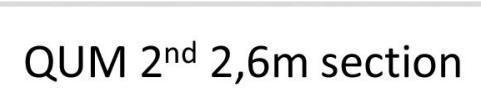

$100 \%$

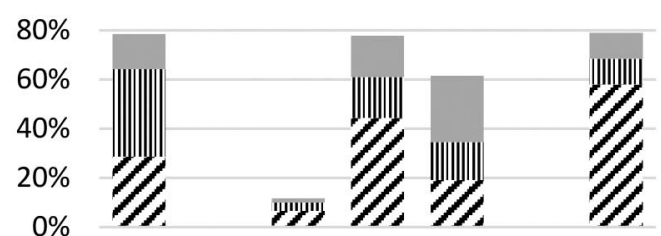

26-I 26-M 27-Lb 29-C 29-H 29-M 29-S

2 4 faces III 3 faces $\quad 2$ faces 1 face

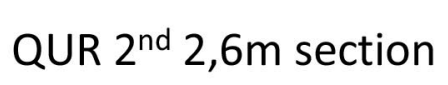

$\mathrm{H}$

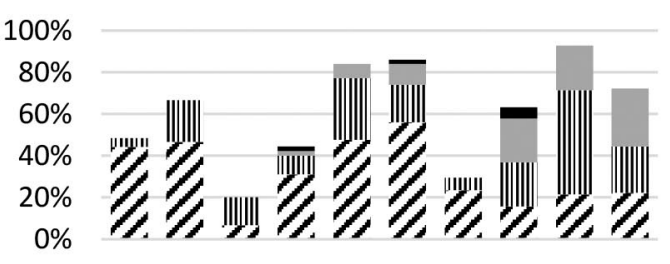

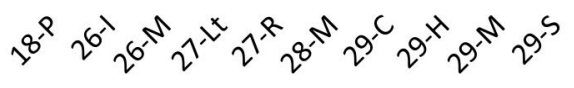

$$
\begin{aligned}
& \text {. } 4 \text { faces III } 3 \text { faces } \square \text { faces } \square 1 \text { face }
\end{aligned}
$$

Fig. 2. Percentage of flawless faces for the first and the second bole length for each species at each plantation age 
The plantations of red oak have more than $78 \%$ of trees with first logs without defects, with nine plantations out of 10 with more than $88 \%$ (Fig. $2 \mathrm{G}$ ). The amount of red oak second logs without defects are from $30 \%$ to $56 \%$ of trees for five plantations, and from $7 \%$ to $24 \%$ for the five other plantations (Fig. 2H). As for bur oak, the addition of red oak second logs with three perfect faces provides a significant increase in red oak value in these plantations (Fig. 2G).

\section{Main defects}

There is a small proportion of trees that have defects on their first log but far more have them on their second log (Fig. 2). Among the trees with stem defects, the presence of large branches ( $>5 \mathrm{~cm}$ diameter) was the most frequent defect encountered in all species (Table 5). Less frequently seen on first logs, and notably absent on bur oak first logs, large branches are the most frequent cause of quality reduction of the second logs of the four study species. The pruning of these branches could have been done earlier but several factors usually justify the delay. Most often these branches cannot all be removed at the same time without weakening the tree, and good judgement must be exercised in choosing which ones to prune. This work also requires more effort and precision when using a pole saw. Subsidies for pruning, when they exist, are limited and address only the initial pruning, mostly for the first log. Large branches on the second log can also appear early on and their removal creates a risk for the sanitary status of the tree. A frequent survey of the trees can help avoid this problem but it can be very time-consuming for the silviculturist. The presence of checks and curves are also frequent defects on the first log of black walnut (Table 5). Checks were also observed on the second logs of sugar maple (Table 5). Cracks, deep or superficial, are also among the defects

Table 5. Proportion of each of the main defects [ $>10 \%$ ] encountered on the $1^{\text {st }}$ and $2^{\text {nd }} 2.6 \mathrm{~m}$ log sections among boles showing defects

\begin{tabular}{llll}
\hline $\mathbf{1}^{\text {st }}$ Log Section & \multicolumn{3}{c}{$\mathbf{2}^{\text {nd }}$ Log Section } \\
\hline ACS & & ACS & \\
Large branches & $42 \%$ & Large branches & $54 \%$ \\
Deep Straight Cracks & $17 \%$ & Epicormic branches & $23 \%$ \\
Knots & $17 \%$ & Checks & $15 \%$ \\
& & JUN & \\
JUN & $27 \%$ & Large branches & $72 \%$ \\
Checks & $19 \%$ & Epicormic branches & $11 \%$ \\
Large branches & $11 \%$ & & \\
Curves & $11 \%$ & & \\
Superficial straight cracks & & \\
& & QUM & \\
QUM & $100 \%$ & Large branches & $65 \%$ \\
Sapsucker pecks & & Epicormic branches & $33 \%$ \\
& & & \\
QUR & & QUR & $60 \%$ \\
Large branches & $39 \%$ & Large branches & \\
Superficial straight cracks & $16 \%$ & Epicormic branches & $28 \%$ \\
Epicormic branches & $13 \%$ & & \\
\hline
\end{tabular}

ACS=Acer saccharum; JUN= Juglans nigra; QUM=Quercus macrocarpa; QUR=Quercus rubra recorded for three of the four species examined, with none seen on bur oak (Table 5). Less frequent defects of the first logs consisted of knots (sugar maple) and epicormic branches (red oak) (Table 5). These epicormic branches were, however, most often the cause of the reduction in quality of the second logs for all the studied species (Table 5). The main defect of the first log of bur oaks was the presence of pecking holes by the yellow-bellied sapsucker (Sphyrapicus varius L.), but it was seen only in plantations M-26 and M-29 (Fig. 2E, Table 5).

European recommendations for final tree densities in intensive silviculture hardwood plantations mention an objective of 50 to 70 stems/ha for black walnut (Becquey 1997) and from 80 to 200 stems/ha for red oak (Bartoli and Golf 1994; Kenk and Borsy 1994; Thill 1994). These densities are designed to rapidly produce high quality, large first logs, and require several thinning operations. If our current results remain stable over time for our study plantations, the selection of best future trees could allow us to obtain a very high majority of first logs without defects for the four species. However, thinning operations will not guarantee the production of a second perfect log in all plantations. Using the final maximum plantation densities mentioned above, we can expect producing a majority of second perfect logs in the case of two out of four plantations for sugar maple, four out of six plantations for black walnut, three out of seven plantations for bur oak, and of five out of 10 plantations for red oak.

\section{Conclusions}

The highest mean annual diameter increments were produced by red oak $\left(0.83 \mathrm{~cm} \mathrm{yr}^{-1}\right)$ and black walnut $\left(0.75 \mathrm{~cm} \mathrm{yr}^{-1}\right)$. Growth was slower for bur oak $\left(0.55 \mathrm{~cm} \mathrm{yr}^{-1}\right)$ and sugar maple $\left(0.51 \mathrm{~cm} \mathrm{yr}^{-1}\right)$. These mean annual diameter increments are comparable to, or exceed, the best rates found in the literature. Our elite trees ( $\mathrm{DBH}+50 \%)$ have diameters that are $17 \%$ to $23 \%$ above the average. In natural hardwood forests, most trees retain their initial quality over time (Power and Havreljuk 2016). By continuing thinning operations, the maximum growth rate of our elite trees could be maintained. With those trees, stems $45 \mathrm{~cm}$ $\mathrm{DBH}$ could be obtained near to 47 years for red oak, near to 51 years for black walnut, and near to 72 years for bur oak and 77 years for sugar maple. These estimates are based on a smaller number of plantations in the case of sugar maple.

Some of the plantation plots we studied have small areas and this may reduce the potential to generalize the results we obtained. However, the frequent silvicultural interventions required for hardwood plantations in order to produce quality timber, tend to restrict the size of new planted areas established annually, generally from 0.5 ha to 5 ha on private land (Thill 1994; Timbal et al. 1994). Von Althen (1990) noted that these conditions make hardwood planting especially suitable for the small landowner and hobby farmer who may have the time, interest, pride and money to make the plantings a success. In addition, new agroforestry systems are currently being proposed to mitigate the effects of forest fragmentation, the loss of biodiversity and the impacts of intensive agriculture (Jose 2009). These objectives aim at providing ecosystem services for the benefit of society. In addition to the positive environmental effects of these new plantation systems, their profitability 
has been established in some cases, as with walnut timber (Graves et al. 2007; Wolz and Delucia 2019). We hope that the results presented here incite various levels of government to support forest and agricultural landowners in their hardwood plantation endeavours.

\section{Acknowledgements}

We gratefully acknowledge and wish to thank the Ministère des forêts de la faune et des parcs (MFFP) of Quebec for its contribution to this research by providing planting stock and research funding, and through its programs of assistance to landowners. Many thanks to Luc Dumouchel, Agence forestière de la Montérégie, and René Dulude, For. Ing. for their help and their belief in the future of hardwood plantations. We also wish to thank Pascal Gauthier (MFFP) and Michel Martin (Coop Unifrontières) for their help with the tree stem evaluation method. We are grateful to Antoine Magnoux and Jacques Baril for their help with field work and database compilation. We express our highest gratitude to all of the landowners on whose properties the plantations were established, and we thank them for their valuable contributions over many years.

\section{References}

Alam, M., A. Olivier, A. Paquette, J. Dupras, J-P. Revéret and C. Messier. 2014. A general framework for the quantification and evaluation of ecosystem services of tree-based intercropping systems. Agrofor. Sys. 88(4): 679-691. doi:10.1007/s10457-014-9681-x. Allen, J.A., B.D. Keeland, J.A. Stanturf, A.F. Clewell and H. Kennedy Jr. 2001. A guide to bottomland hardwood restoration. Information and Technology Report, USGS/BRD/ITR-20000011, Gen. Tech. Rep. SRS-40, USDA Forest Service.

Balleux, P. and P. van Lerberghe. 2001. Le boisement des terres agricoles. Institut du développement forestier, Paris. 128 p.

Bariteau, L. 1988. La carte géomorphologique au 1:20 000 de modelés polygéniques: un exemple des basses terres du SaintLaurent. Mémoire de maîtrise, Université de Montréal, Montréal. Bartoli, M. and N.L. Golf. 1994. La conduite des peuplements en France. In: Le chêne rouge d'Amérique. J. Timbal, A. Kremer, N.L. Goff, and G. Nepveu (eds). Institut national de la recherche agronomique, Paris. pp. 237-246.

Becquey, J. 1997. Les noyers à bois. $3^{\text {rd }}$ edition, Les Guides du Sylviculteur, Institut pour le développement forestier, Paris. p. 60-61.

Bergeron, M., S. Lacombe, R.L. Bradley, J. Whalen, A. Cogliastro, M.-F. Jutras and P. Arp. 2011. Reduced soil nutrient leaching following the establishment of tree-based intercropping systems in eastern Canada. Agrofor. Sys. 83: 321-330. doi:10.1007/s10457-011-9402-7.

Bohanek, J.R. and J.W. Groninger. 2003. Impacts of intensive management on black walnut (Juglans nigra L.) growth and bole quality at mid-rotation. For. Sci. 49: 522-529.

Cogliastro, A., D. Gagnon and A. Bouchard. 1997a. Experimental determination of soil characteristics optimal for the growth of ten hardwoods planted on abandoned farmland. For. Ecol. Manag. 96: 49-63.

Cogliastro, A., D. Gagnon and A. Bouchard. 1997b. Is site preparation necessary for bur oak receiving post-planting weed control ? Ann. For. Sci. 54: 107-116.

Cogliastro, A., D. Gagnon, D. Coderre and P. Bhereur. 1990. Responses of seven hardwood tree species to herbicide, rototilling, and legume cover at two southern Quebec plantation sites. Can. J. For. Res. 20(8): 1172-1182.

Cogliastro, A., D. Gagnon, S. Daigle and A. Bouchard. 2003. Improving hardwood afforestation success: An analysis of the effects of soil properties in southwestern Quebec. For. Ecol. Manag. 177: 347-359.

Davies, R.J. 1988. Sheet mulching as an aid to broadleaves tree establishment I. The effectiveness of various synthetic sheets compared. Forestry 61: 89-105.

Farlee, L.D. 2018. Resources and assistance available for planting hardwood seedlings. Available from https://www.extension.purdue.edu/extmedia/FNR/FNR-226-w.pdf [cited 2 may 2019].

Gardiner, E.S., D.R. Russell, M. Oliver and L.C. Dorris. (2002). Bottomland hardwood afforestation: state of the art. In: Proceedings of a Conference on Sustainability of Wetlands and Water Resources, May 23-25, Oxford, Mississippi, Marjorie M. Holland, Melvin L. Warren, John A. Stanturf (eds). p. 75-86.

Genet, A., D. Auty, A. Achim, M.D.P. Bernier and A. Cogliastro. 2013. Consequences of faster growth for wood density in northern red oak (Quercus rubra Liebl.). Forestry 86: 99-100. doi:10.1093/forestry/cps057.

Globensky,Y. 1987. Géologie des Basses-Terres du Saint-Laurent, Rapport MM 85-02, Québec: Ministère de l'énergie et des ressources, Direction générale de l'exploration géologique et minérale, $63 \mathrm{p}$.

Graves, A.R., P.J. Burgess, J.H.N. Palma, F. Herzog, G. Moreno, M. Bertomeu, C. Dupraz, F. Liagre, K. Keesman, W. van der Werf, A.K. de Nooy and J.P. van den Briel. 2007. Development and application of bio-economic modelling to compare silvoarable, arable, and forestry systems in three European countries. Ecol. Eng. 29: 434-449.

Hubert, M. and Courraud, R. 1998. Élagage et taille de formation des arbres forestiers. Institut pour le développement forestier. Paris. 303 p.

Johnson, P.S. 1990. Quercus macrocarpa Michx. In: Silvics of North America: 2. Hardwoods, Agriculture Handbook 654. USDA, Forest Service, Washington, DC. pp. 686-692.

Johnson, P.S., Shifley, S.R., and Rogers, R. 2009. Ecology and Silviculture of Oaks - 2nd ed. CABI North American Office, Cambridge, MA.

Jose, S. 2009. Agroforestry for ecosystem services and environmental benefits: an overview. Agrofor. Sys. 76: 1-10.

Kenk, G. and P. Borsy. 1994. Le chêne rouge (Quercus borealis Michx.) en Allemagne. In Le chêne rouge d'Amérique. J. Timbal, A. Kremer, N.L. Goff, and G. Nepveu (eds). Institut national de la recherche agronomique, Paris. pp. 265-271.

Lambert, M.-C., C.-H. Ung and F. Raulier. 2005. Canadian national tree aboveground biomass equations. Can. J. Forest. Res. 35: 1996-2018.

Lamson, N. I. and H.C. Smith. (1978). Response to crop-tree release: Sugar maple, red oak, black cherry, and yellow-poplar saplings in a 9-year-old stand. Res. Pap. NE-394. Broomall, PA: USDA, Forest Service, Northeastern Exp. Station.

McKenney, D., D. Allen, S. Fraleigh, J. Pedlar and K. Campbell. 2008. Growth of southern Ontario hardwood research plantations. Can. For. Serv. Great Lakes For. Cent. Inf. Rep. 2562-0738; GLC-X-9E.

Meilleur, A., A. Bouchard and Y. Bergeron. 1994. The relation between geomorphology and forest community types of the Haut-St-Laurent, Québec. Vegetatio 111: 173-192.

MELCC. 2010. Climate summary 1981-2010. Available from http://www.environnement.gouv.qc.ca/climat/normales/sommaire.asp [cited February 2019].

MFFP. 2014. Classification des tiges d'essences feuillues [Hardwood stem classification, in French]. Ministère des Forêts, de la Faune et des Parcs Secteur des forêts, Direction des inventaires forestiers. Québec. Available from https://mffp.gouv.qc.ca/publications/forets/connaissances/classif-tiges-essence-feuillues-6.pdf [cited april 2019].

Ostfeld, R.S., R.H. Manson and C.D. Canham. 1997. Effects of rodents on survival of tree seeds and seedlings invading old fields. Ecology 78: 1531-1542. 
Pedlar, J.H., D.W. McKenney and S. Fraleigh. 2006. Planting black walnut in Southern Ontario: midrodation assessment of growth, yield, and silvicultural treatments. Can. J. For. Res. 36: 495-504.

Pedlar, J.H., S. Fraleigh and D.W. McKenney. 2007. Revisiting the work of Fred von Althen - an update on the growth and yield of a mixed hardwood plantation in Southern Ontario. For. Chron. 83: 175-179.

Power, H. and F. Havreljuk. 2016. Predicting hardwood quality and its evolution over time in Quebec's forests. Forestry 91: 259270. doi:10.1093/forestry/cpw059\%.

Saura, S., L. Bastin, L. Battistella, A. Mandrici and G. Dubois. 2017. Protected areas in the world's ecoregions: How well connected are they? Ecol. Indi. 76: 144-158.

Stanturf, J.A., S.H. Schoenholtz, C.J. Schweitzer, C.J. and J.P. Shepard. 2001. Achieving restoration success: Myths in bottomland hardwood forests. Restor. Ecol. 9: 189-200.

Thill, A. 1994. La sylviculture du chêne rouge d'Amérique en Belgique. In: Le chêne rouge d'Amérique. J. Timbal, A. Kremer, N.L. Goff, and G. Nepveu (eds). Institut national de la recherche agronomique, Paris. pp. 254-264.

Timbal, J., B. Pilard-Landeau, B. Lemoine and J. Gelpe. 1994. Le chêne rouge d'Amérique dans le Sud-Ouest de la France. In: Le chêne rouge d'Amérique. Institut National de la Recherche Agronomique, France, Paris. pp. 151-176.
Truax, B. and D. Gagnon. 1993. Effects of straw and black plastic mulching on the initial growth and nutrition of butternut, white ash and bur oak. For. Ecol. Manage. 57: 17-27.

Truax, B., D. Gagnon, F. Lambert and J. Fortier. 2015. Multiple-use zoning model for private forest owners in agricultural landscapes: A case study. Forests 6: 3614-3664.

von Althen, F.W. 1990. Hardwood planting on abandoned farmland in southern Ontario: Revised guide. Minister of Supply and Services Canada. Catalogue No. Fo 42-150/1990E.

Ward, J.S. 2002. Crop tree release increases growth of mature red oak sawtimber. North. J. Appl. For. 19: 149-154.

West, P.W. 2006. Growing plantation forests. Springer-Verlag Berlin Heidelberg.

Woeste, K.E. 2002. Heartwood production in a 35-year-old black walnut progeny test. Can. J. For. Res. 32: 177-181.

Wolz, K.J. and E.H. Delucia. 2019. Black walnut alley cropping is economically competitive with rowcrops in the Midwest USA. Ecol. Appl. 29: e01829.

Zhang, Y., C. Peng, W. Li, L. Tian, Q. Zhu, H. Chen and Z. Li. (2016). Multiple afforestation programs accelerate the greenness in the 'Three North'region of China from 1982 to 2013. Ecol. Indic. 61: 404-412. 